\title{
Kinerja Lingkungan, Manajemen Laba, Corporate Governance Dan Corporate Social Responsibility (CSR)
}

\author{
Putu Purnama Dewi ${ }^{1}$ \\ I Gusti Ayu Emi Eka Yanti²
${ }^{1,2}$ Fakultas Ekonomi dan Bisnis Universitas Pendidikan Nasional (Undiknas), Bali, Indonesia
e-mail : purnamadewi@undiknas.ac.id

\begin{abstract}
ABSTRAK
Penelitian mengenai pengaruh kinerja lingkungan terhadap corporate social responsibility masih jarang diteliti. Namun untuk pengaruh manajemen laba dan corporate governance terhadap corporate social responsibility sebelumnya telah banyak diteliti. Komponen corporate governance yang digunakan dalam penelitian ini adalah kepemilikan institusional, kepemilikan manajerial, ukuran dewan komisaris dan komite audit. Penelitian ini bertujuan untuk mengetahui adanya pengaruh antara kinerja lingkungan, manajemen laba dan corporate governance terhadap corporate social responsibility dengan menggunakan perusahaan tambang yang telah terdaftar di bursa efek Indonesia dan juga terdaftar dalam PROPER. Dalam penelitian ini menggunakan metode analisis regresi berganda dengan menggunakan 45 sampel yang telah menunjukan hasil penelitian bahwa hanya kinerja lingkungan yang memiliki pengaruh terhadap corporate social responsibility, sedangkan manajemen laba, kepemilikan institusional, kepemilikan manajerial, ukuran dewan komisaris dan komite audit tidak berpengaruh terhadap corporate social responsibility.
\end{abstract}

Kata kunci : Kinerja lingkungan, manajemen laba, corporate governance dan corporate social responsibility.

\section{ABSTRACT}

Research on the influence of environmental performance on corporate social responsibility is still rarely studied. However, the influence of earnings management and corporate governance on corporate social responsibility has been investigated. This study used institutional ownership, managerial ownership, board of commissioners and audit committees as corporate governance's proxy. This study aimed to investigate the influence of environmental performance, earnings management and corporate governance on corporate social responsibility by using mining companies that have been listed on the Indonesian stock exchange and are also registered with PROPER. In this study using multiple regression analysis method with 45 samples which showed the results of research that only environmental performance had an influence on corporate social responsibility, while earnings management, institutional ownership, managerial ownership, board of commissioners and audit committees did not affect corporate social responsibility.

Keywords : Environmental performance, earnings management, corporate governance, corporate social responsibility.

\section{PENDAHULUAN}

Dewasa ini di Indonesia isu mengenai kerusakan alam masih menjadi topik hangat untuk diperbincangkan. Eksploitasi alam yang berlebihan tidak bisa lepas dari 
kegiatan suatu perusahaan khususnya perusahaan tambang yang memerlukan sumber daya alam dalam kegiatan usahanya. Namun sangat disayangkan ketika ekploitasi dilakukan tidak diimbangi dengan perbaikan lingkungan ataupun keseimbangan alam dan lingkungan sekitarnya, tentu tindakan ini merugikan kehidupan sekitar lingkungan termasuk juga masyarakat yang terkena imbasnya. Permasalahan lingkungan ini di Indonesia perlu dikaji secara mendalam supaya dapat dilakukan tindakan pencegahan dan perbaikan yang tepat sesuai kondisi sekitarnya. Pemerintah melalui Kementrian Lingkungan Hidup membentuk Program Penilaian Peringkat Kinerja Perusahaan dalam Pengelolaan Lingkungan Hidup (PROPER) yang telah dilaksanakan mulai tahun 2002 dibidang pengendalian dampak lingkungan untuk meningkatkan program pelestarian lingkungan hidup.

Diluar dari isu mengenai lingkungan, perusahaan juga dituntut untuk peduli terhadap para stakeholder. Sesuai dengan konsep triple bottom lines bahwa selain mencari keuntungan (profit), perusahaan juga perlu memikirkan mengenai lingkungan sekitarnya (planet) dan kepada para pemangku kepentingan (people). Perusahaan bisa menjadikan konsep tersebut sebagai acuan untuk menerapkan corporate social responsibility atau yang lebih disebut dengan CSR. Penerapan CSR dalam sebuah perusahaan dapat berpengaruh positif dengan kinerja perusahaan dalam berbagai perspektif yang berbeda. Tetapi hal ini tidak menjamin bahwa perusahaan tidak melakukan kecurangan dalam pelaporan keuangannya. Menurut (Machmuddah et al., 2017) mengungkapkan bahwa lingkungan perusahaan dapat digunakan untuk mengalihkan perhatian pemegang saham dari 
pengawasan aktivitas manajemen laba. Para manajer yang terlibat dalam praktik manajemen laba termotivasi untuk berperilaku secara proaktif agar menunjukan sisi positif kepada para pemegang saham dan kelompok pemangku kepentingan yang berbeda untuk menjamin kinerja yang optimal.

Maraknya praktik manajemen laba saat ini tidak terlepas dari lemahnya penerapan corporate governance. Menurut Forum for corporate governance in Indonesia FCGI (Ningsaptiti, 2010) tujuan dari corporate governance mengendalikan perilaku pengelola perusahaan agar bertindak tidak hanya menguntungkan dirinya sendiri, tetapi juga menguntungkan pemilik perusahaan, sehingga dapat menyamakan kepentingan antara pemilik perusahaan dengan pengelola perusahaan. Konsep ini diajukan demi tercapainya pengelolaan perusahaan yang lebih baik bagi semua pengguna laporan keuangan. Komponen corporate governance yang akan diteliti pada penelitian ini terdiri dari empat proksi yaitu kepemilikan instutional yang diasumsikan akan membantu dalam mendorong perusahaan untuk lebih melakukan pengungkapan CSR karena tuntutan dari pihak institusi untuk lebih luas dalam pengungkapan informasi perusahaan khususnya terkait dengan sosial, lalu kepemilikan manajerial yang terdiri dari kepemilikan saham oleh pihak manajemen, hal ini akan membuat manajemen melakukan segala upaya untuk menjaga kinerja perusahaan agar tidak mengalami kerugian dan meningkatkan nilai perusahaan, salah satunya dengan pelaksanaan CSR untuk meningkatkan kualitas perusahaan dimata stakeholder dan juga calon investor agar tertarik menanamkan modal ke perusahaan. Selanjutnya adalah variabel ukuran dewan komisaris, dewan komisaris merupakan 
mekanisme corporate governance yang memiliki fungsi tertinggi terkait pengendalian intern perusahaan yang bertanggung jawab untuk mengawasi kinerja manajemen, fungsi ini membuat dewan komisaris mempunyai wewenang untuk menentukan pengungkapan informasi perusahaan termasuk pengungkapan CSR. Yang terakhir adalah variabel komite audit yang merupakan kesatuan yang dibentuk dan berada dibawah dewan komisaris. Tugas dari komite audit merupakan membantu dewan komisaris dalam mengawasi internal perusahaan agar meminimalisir hal hal buruk yang akan mempengaruhi kinerja perusahaan karena hal ini akan berdampak dengan menurunnya penungkapan tanggung jawab sosial atau CSR.

Terkait dengan permasalahan diatas, penelitian ini akan menggunakan sampel perusahaan tambang karena perusahaan tambang merupakan salah satu usaha yang berpengaruh besar terhadap lingkungan dan keberlangsungan hidup sekitar. Asumsi tersebut muncul karena perusahaan tambang termasuk perusahaan yang secara langsung melakukan eksplorasi dan eksploitasi sumber daya alam yang menyebabkan kerusakan lingkungan sehingga berpengaruh ke kehidupan masyarakat. Semakin besar skala kegiatan perusahaan maka semakin besar pula dampaknya bagi lingkungan sekitar.

Teori agensi merupakan teori yang memisahkan antara agen dan prinsipal. Hal ini disebabkan karena hubungan keagenan selalu menimbulkan permasalahan antara pemilik dan agen karena terjadinya perbedaan pola pikir serta perbedaan kepentingan yang menonjol. Oleh karena itu diperlukan konsep teori keagenan 
untuk menjelaskan adanya hubungan antara manajemen dan pemilik yang memiliki kepentingan berbeda.

Dalam menjalankan bisnisnya perusahaan tidak hanya memikirkan kepentingan pihak internal namun juga perlu memikirkan kepentingan dari pihak eksternal perusahaan yaitu masyarakat sekitar dan lingkungannya. Menurut A. Purwanto (2011) teori legitimasi adalah kegiatan atau aktivitas yang dilakukan oleh perusahaan yang tidak melanggar norma-norma masyarakat yang berlaku. Teori legitimasi bergantung pada kontrak sosial antara perusahaan dengan masyarakat sekitar. Kontrak sosial merupakan upaya dalam menjelaskan besarnya harapan masyarakat tentang bagaimana seharusnya organisasi melaksanakan operasinya. Perusahaan dapat menggunakan disclosure untuk menarik perhatian manajemen akan nilai sosial, atau untuk mengarahkan kembali perhatian akan pengaruh negatif akibat aktivitas bisnis.

Teori sinyal menekankan kepada pentingnya informasi yang dikeluarkan oleh perusahaan terhadap keputusan investasi pihak di luar perusahaan. Informasi adalah unsur penting bagi investor dan pelaku bisnis untuk mengetahui catatan atau gambaran baik atau buruknya keadaan masa lalu, saat ini maupun keadaan masa yang akan datang bagi kelangsungan hidup suatu perusahaan dan bagaimana pasaran efeknya. Dorongan perusahaan untuk memberikan informasi karena terkadang masih terdapat asimetri informasi antara perusahaan dan pihak luar karena perusahaan mengetahui lebih banyak mengenai perusahaan dan prospek yang akan datang daripada pihak luar (investor dan kreditor). 
Penelitian sebelumnya oleh Sudaryanto (2011) mengatakan bahwa perusahaan dengan kinerja lingkungan yang baik perlu mengungkapkan informasi kuantitas dan mutu lingkungan yang lebih baik dibandingkan perusahaan dengan perusahaan yang memiliki kinerja lingkungan yang buruk. Hasil penelitian oleh Bahri and Cahyani (2016) juga mengungkapkan adanya pengaruh signifikan antara kinerja lingkungan dengan corporate social responsibility. Berdasarkan penelitian tersebut, maka hipotesis pertama penelitian ini dirumuskan :

$\mathrm{H}_{1}$ : Ada pengaruh positif dan signifikan dari kinerja lingkungan terhadap corporate social responsibility.

Manajemen laba adalah praktik yang dilakukan oleh manajer untuk memanipulasi laporan keuangan perusahaan untuk kepentingan manajer itu sendiri. Menurut Prior et al (2008) dalam Fajrina (2014) untuk mengamankan posisinya, manajer menggunakan pengungkapan CSR sebagai alat untuk mengalihkan isu terkait praktik manajemen laba yang dilakukan. Namun dari hasil penelitian lain yaitu oleh Djuitaningsih and Marsyah (2016) mengungkapkan bahwa manajemen laba berpengaruh negatif terhadap corporate social responsibility. Berdasarkan penelitian tersebut, peneliti ingin menguji kembali pengaruh antara manajemen laba dengan corporate social responsibility. maka hipotesis kedua penelitian ini dirumuskan:

$\mathrm{H}_{2}$ : Ada pengaruh positif dan signifikan dari manajemen laba terhadap corporate social responsibility 
Tingkat kepemilikan institusional yang tinggi dalam suatu perusahaan dapat membantu dalam memperkuat mekanisme pengawasan atau kontroling. Tingginya tingkat pengawasan yang dilakukan investor dapat mengurangi pihak manajer dalam melakukan kegiatan yang merugikan perusahaan. Kepemilikan institusional dalam jangka panjang dapat berpengaruh positif untuk meningkatkan keputusan perusahaan dalam pengungkapan tanggung jawab sosial. Hasil penelitian Setyarini and Paramitha (2011) menunjukkan bahwa kepemilikan institusional berpengaruh positif terhadap pengungkapan CSR perusahaan. Menurutnya persentase kepemilikan instusional yang tinggi diharapkan dapat membuat perusahaan mengungkapkan tanggung jawab sosial yang lebih luas. Berdasarkan asumsi tersebut maka hipotesis ketiga pada penelitian ini adalah :

$\mathrm{H}_{3}$ : Ada pengaruh positif dan signifikan dari proksi kepemilikan instusional terhadap corporate social responsibility.

Selain kepemilikan institusional, Kepemilikan manajerial dalam suatu perusahaan juga dapat menyebabkan berkurangnya tindakan manajemen laba dari pihak manajer. Pihak manajer akan mengambil keputusan yang kedepannya akan menguntungkan perusahaan, seperti keputusan yang dapat meningkatkan nilai perusahaan, keputusan yang dapat menarik minat calon investor agar investasi yang telah dilakukan pihak manajer dapat menguntungkan bagi dirinya. Salah satu kegiatan yang dapat dilakukan adalah dengan pengungkapan CSR untuk meningkatkan nilai perusahaan dimata stakeholder. Penelitian terkait pengaruh manajemen laba terhadap pengungkapan CSR telah banyak diteliti dan menunjukan hasil yang berbeda beda, seperti hasil penelitian oleh Terzaghi (2016) 
Putu Purnama Dewi dan I Gusti Ayu Emi Eka Yanti. Kinerja ...

yang menyatakan bahwa manajemen laba tidak berpengaruh terhadap pengungkapan CSR namun hasil menurut Setyarini and Paramitha (2011); Khan et al (2013) menunjukkan adanya pengaruh yang positif dan signifikan antara kepemilikan manajemen terhadap corporate social responsibility. Berdasarkan asumsi tersebut hipotesis keempat pada penelitian ini adalah :

$\mathrm{H}_{4}$ : ada pengaruh positif dan signifikan dari proksi kepemilikan manajerial terhadap corporate social responsibility

Dewan komisaris sebagai mekanisme corporate governance memiliki peran penting dalam bagian pengawasan yaitu sebagai pihak yang bertugas mengawasi dan mengelola perusahaan. Ukuran dewan komisaris yang besar dalam perusahaan akan meningkatkan pengawasan terkait pengelolaan perusahaan, termasuk pengungkapan CSR. Hasil penelitian menurut Sembiring (2005) dan Jayanti (2018) menyatakan bahwa ada pengaruh positif antara ukuran dewan komisaris dengan CSR. Asumsi ini merujuk pada semakin besar ukuran dewan komisaris maka semakin mudah untuk mengontrol kinerja manajemen khususnya terkait dengan pelaksanaan CSR. Berdasarkan asumsi tersebut maka hipotesis kelima pada penelitian ini adalah :

$\mathrm{H}_{5}$ : ada pengaruh positif dan signifikan dari proksi ukuran dewan komisaris terhadap corporate social responsibility.

Variabel independen terakhir dalam penelitian adalah komite audit yang merupakan komponen corporate governance yang berada dibawah kendali dewan komisaris. Komite audit akan membantu dewan komisaris untuk mengawasi dan memastikan bahwa seluruh pihak internal perusahaan telah mematuhi aturan kerja 
dan menjalankan tugasnya sesuai fungsi masing masing, serta memastikan seluruh kegiatan usaha yang dilakukan perusahaan berjalan dengan baik dan sesuai aturan. Berdasarkan asumsi tersebut maka hipotesis keenam adalah :

$\mathrm{H}_{6}$ : Ada pengaruh positif dan signifikan dari proksi komite audit terhadap corporate social responsibility.

Sesuai dengan pemaparan hipotesis tersebut maka model penelitian ini dapat digambarkan sebagai berikut :

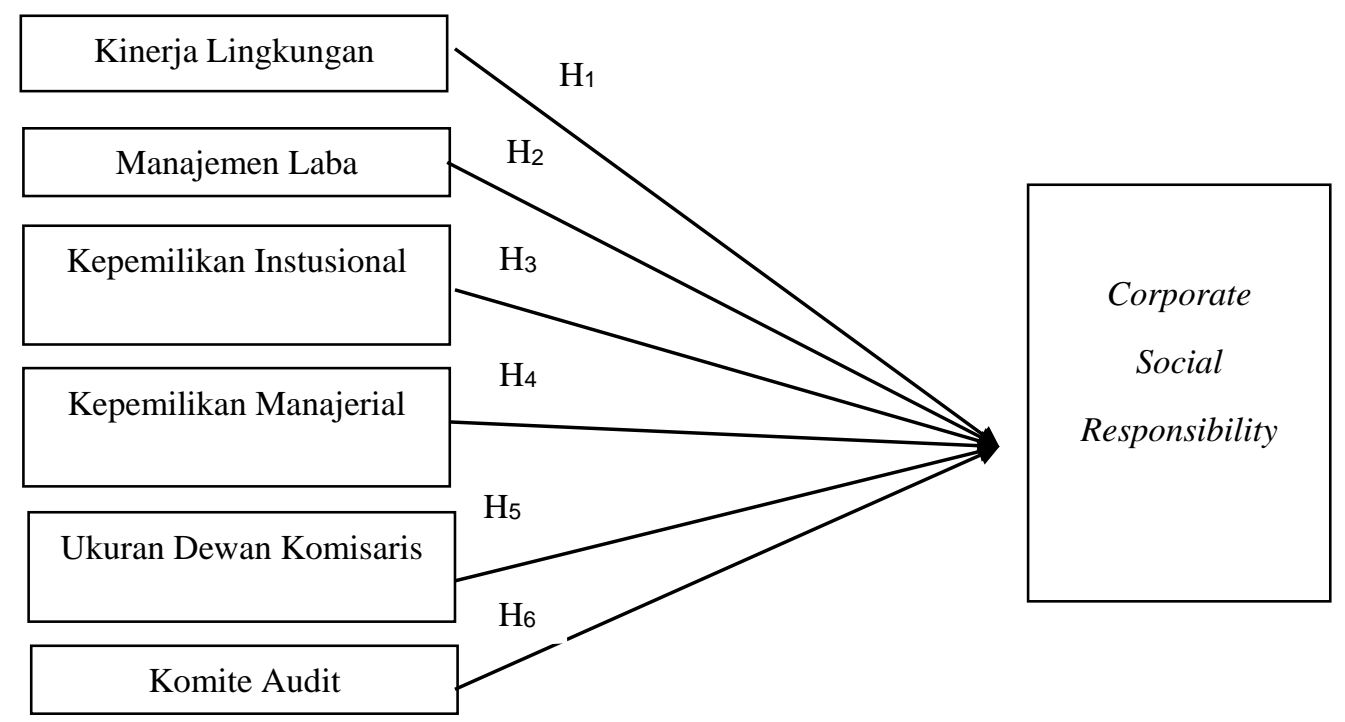

\section{Gambar 1. Model Penelitian}

Sumber : Data diolah, 2019

\section{METODE PENELITIAN}

Sesuai dengan karakteristik masalah yang diteliti penelitian ini menggunakan data perusahaan pertambangan yang sudah terdaftar di Bursa Efek Indonesia periode 2013-2017 dengan kriteria sampel yaitu perusahaan telah mempublikasi laporan tahunan dan pengungkapan CSR secara lengkap serta ikut serta dalam PROPER pada periode 2013-2017. Sumber data dalam penelitian ini adalah data sekunder 
yaitu berupa annual report pada periode 2013-2017 dan data ini termasuk kedalam jenis data kuantitatif.

Teknik analisis data yang digunakan untuk mengukur indeks CSR adalah adalah rumus perhitungan sebagai berikut (Sembiring, 2005) :

$\operatorname{CSRI}_{j}=\frac{\sum \mathrm{X}_{\mathrm{ij}}}{n_{j}}$

Sedangkan pada kinerja lingkungan dalam penelitian ini akan diukur melalui presentasi perusahaan dalam mengikuti PROPER. Sistem penilaian kinerja PROPER mencakup pemeringkat dalam 5 warna yaitu : Emas (skor 5), Hijau (skor 4), Biru (skor 3), Merah (skor 2) dan Hitam (skor 1).

Manajemen laba dapat dihitung dengan model yang telah dikembangkan oleh (Dechow 1995) dengan empat tahap perhitungan yaitu :

Penentuan total akrual dengan cash flow :

$T A C_{i t}=\mathrm{NI}_{\mathrm{it}}-\mathrm{CFOit}$

Keterangan :

$T A C_{i t}=$ Total akrual perusahaan

NI $I_{i t}=$ Laba bersih perusahaan

CFOit $=$ Arus kas dari aktivitas operasi

Penentuan koefisien regresi dengan total akrual :

TAit/Ait $-1=\beta 1(1$ Ait -1$)+\beta 2(\Delta$ Revit Ait -1$)+\beta 3($ PPEit Ait -1$)+\varepsilon_{. .}(3)$

Keterangan :

TAit $1=$ Total akrual perusahaan

Ait $-1=$ Total aset perusahaan

$\Delta \mathrm{REV}_{\text {it }}=$ Perubahan pendapatan

perusahaan 
$\Delta \mathrm{REC}_{i t}=$ Perubahan piutang bersih perusahaan

$\mathrm{PPE}_{i t}=$ Property, plant and equipment perusahaan

Penentuan Nondiscretionary accrual :

NDAit $=\beta 1(1$ Ait -1$)+\beta 2(\Delta$ Revit Ait $-1-\Delta$ Recit Ait -1$)+\beta 3($ PPEit Ait-1).

Keterangan :

NDAit $=$ Nondiscretionary accrual

Perusahaan

Dan yang terakhir adalah menentukan Discretionary accrual dengan rumus :

$$
\text { DAit }=\text { TAit Ait }-1-N D A i_{\mathrm{t}}
$$

Keterangan :

DAit $=$ Discretionary accrual perusahaan

Kepemilikan institusional merupakan kepemilikan saham oleh institusi dalam hal ini institusi pendiri perusahaan, bukan institusi pemegang saham publik. Rumus untuk menentukan persentase kepemilikan institusional adalah :

$\underline{\Sigma \text { Saham Institusional }}$ $\Sigma$ Saham Beredar

Kepemilikan manajerial merupakan tingkat kepemilikan saham pihak manajemen yang secara aktif ikut dalam pengambilan keputusan perusahaan (direktur dan komisaris). Rumus untuk menentukan persentase kepemilikan manajerial adalah :

$\underline{\Sigma \text { Saham milik manajemen }}$

$\Sigma$ Saham beredar 
Peranan dewan komisaris dapat dilihat dari karakteristik dewan, salah satunya adalah komposisi keanggotaanya. Efektivitas fungsi pengawasan dewan tercermin dari komposisinya, terkait dengan pengangkatan anggota dewan berasal dari dalam perusahaan dan atau dari luar perusahaan. Rumus untuk menentukan persentase ukuran dewan komisaris adalah :

$\Sigma$ Dewan komisaris independen

$\Sigma$ Anggota dewan komisaris

Komite audit merupakan sebuah komite yang ditunjuk oleh perusahaan sebagai penghubung antara dewan direksi dan audit eksternal, internal auditor serta anggota independen. Komite audit ditugaskan untuk memberikan pengawasan pada auditor perusahaan internal dan eksternal. Rumus untuk menentukan rasio komite audit adalah:

$\Sigma$ Anggota komite audit

\section{HASIL DAN PEMBAHASAN}

Dengan metode purposive sampling terdapat sebanyak 45 sampel yang telah memenuhi kriteria yang diambil dari laporan tahunan dan laporan hasil PROPER perusahaan Tambang yang terdaftar di Bursa Efek Indonesia.

Dalam penelitian ini uji asumsi klasik yang digunakan adalah uji normalitas, multikolineritas, autokorelasi dan heterokedastisitas. Dari hasil pengujian yang telah dilakukan data penelitian ini telah terbebas dari asumsi klasik.

Berdasarkan hasil perhitungan adjusted $R$ Square pada table 1 telah memperoleh nilai koefisien determinasi $\mathrm{R}^{2}$ sebesar 0,214 atau $21,4 \%$. Hal ini berarti kemampuan seluruh variabel independen yang terdiri dari kinerja 
lingkungan, manajemen laba, dan corporate governance dalam menjelaskan variabel dependen yaitu corporate social responsibility pada perusahaan tambang yang terdaftar di Bursa Efek Indonesia tahun 2013-2017 sebesar 21,4\% sisanya 78,6\% dipengaruhi oleh variabel lain yang tidak diteliti dalam penelitian ini.

Tabel 1.

Uji Koefisien Determinasi

\begin{tabular}{cccc}
\hline Model & R Square & $\begin{array}{l}\text { Adjusted R } \\
\text { Square }\end{array}$ & $\begin{array}{l}\text { Std. Error } \\
\text { of } \\
\text { Estimate }\end{array}$ \\
\hline 1 & $567^{\text {a }}$ & 321 & \multicolumn{2}{c}{, 0993278} \\
\hline Sumber : Data diolah, 2019 & &
\end{tabular}

Pada tabel 2 dapat dilihat hasil nilai signifikasi pada uji f anova sebesar 0,017 dengan nilai hitung f anova sebesar 2,999. Dari hasil tersebut di ketahui bahwa nilai signifikan F 0,017 $<0,05$ yang berarti kinerja lingkungan, manajemen laba, kepemilikan instusional, kepemilikan manajerial, ukuran dewan komisaris dan komite audit berpengaruh secara simultan terhadap corporate social responsibility.

Tabel 2.

Uji F Anova

\begin{tabular}{cccccc}
\hline Model & $\begin{array}{c}\text { Sum of } \\
\text { Squares }\end{array}$ & $d f$ & $\begin{array}{c}\text { Mean } \\
\text { Square }\end{array}$ & $F$ & Sig. \\
\hline 1 Regression &, 178 & 6 &, 030 & 2,999 &, $017^{\mathrm{b}}$ \\
Residual &, 375 & 38 &, 010 & & \\
Total &, 552 & 44 & & & \\
\hline Sumber: Data diolah, 2019 & & &
\end{tabular}

Sumber : Data diolah, 2019

Hasil pengujian hipotesis dilakukan dengan menggunakan regresi berganda pada tabel 3. 
Tabel 3.

Hasil Regresi Berganda

Unstandardized Standardized

\begin{tabular}{|c|c|c|c|c|c|}
\hline & & Coefficients & Coefficients & & \\
\hline Model & $B$ & Std. Error & Beta & $t$ & Sig \\
\hline 1. (Constant) & ,368 & ,144 & & 2,555 &, 015 \\
\hline $\mathrm{X} 1$ & ,042 & ,016 & ,387 & 2,603 & ,013 \\
\hline $\mathrm{X} 2$ & ,197 & 288 & & 685 & 497 \\
\hline $\mathrm{X} 3$ &, 043 & ,072 & $\begin{array}{l}, 105 \\
, 106\end{array}$ &, 595 & ,556 \\
\hline $\mathrm{X} 4$ & ,001 & ,204 & ,001 & ,006 & \\
\hline $\mathrm{X} 5$ &,- 406 & 227 &, $259^{-}$ & 1,793 & סקי, \\
\hline X6 & ,023 & ,028 & , 127 & ,815 & ,420 \\
\hline
\end{tabular}

Sumber : Data diolah, 2019

Berdasarkan hasil tersebut $\mathrm{H}_{1}$ menunjukan adanya pengaruh kinerja lingkungan terhadap corporate social responsibility diperoleh nilai Sig. t sebesar 0,013 dengan nilai koefisien beta 0,387 Nilai Sig. t 0,015<0,05 mengindikasikan bahwa $\mathrm{H}_{0}$ ditolak dan $\mathrm{H}_{1}$ diterima. Jadi sesuai dengan hasil tersebut untuk variabel kinerja lingkungan dinyatakan berpengaruh positif dan signifikan terhadap pengungkapan CSR. Hasil ini selaras dengan penelitian dari Tito Anindito (2015) yang juga menemukan adanya pengaruh kinerja lingkungan terhadap pengungkapan CSR. Ditinjau dari hasil tersebut dapat disimpulkan bahwa pada periode 2013-2017 perusahaan tambang telah melakukan pengelolaan dengan baik untuk lingkungan yang terkena dampak dari kegiatan operasionalnya. Tentu ini mampu menunjukan bahwa perusahaan tambang tidak hanya sebatas melakukan ekplorasi dan eksploitasi bagi lingkungan namun juga secara seimbang memperbaiki dan mengelola lingkungan sesuai dengan kebutuhan lingkungan. 
Dengan terciptanya lingkungan yang baik, perusahaan juga telah memenuhi kontrak sosialnya dengan masyarakat, sehingga tidak ada pihak yang dirugikan karena perusahaan sebagai pihak yang beroperasi telah melakukan upaya terbaik bagi lingkungan sekitar masyarakat tinggal dan masyarakat tidak perlu menerima dampak kerusakan lingkungan yang disebabkan oleh perusahaan.

Hasil analisis $\mathrm{H}_{2}$, pengaruh manajemen laba terhadap corporate social responsibility diperoleh nilai Sig. t sebesar 0,497 dengan nilai koefisien beta 0,105 Nilai Sig. t 0,0,497 > 0,05 mengindikasikan bahwa $\mathrm{H}_{0}$ diterima dan $\mathrm{H}_{1}$ ditolak. Hasil ini menunjukan bahwa Manajemen Laba berpengaruh negatif terhadap Corporate Social Responsibility. Hasil ini sejalan dengan Pasaribu (2011) dan Terzaghi (2016) yang menyatakan bahwa tidak ada pengaruh antara manajemen laba dengan pengungkapan CSR, namun bertolak belakang dengan hasil penelitian yang telah dilakukan oleh Machmuddah et al.,(2017) yang mengungkapkan adanya pengaruh positif antara manajemen laba dengan pengungkapan CSR. Terkait hasil tersebut yang menunjukan bahwa manajemen laba tidak berpengaruh terhadap pengungkapan CSR dapat terjadi dikarenakan pelaksanaan CSR oleh perusahaan lebih didorong agar memperoleh legtimasi sosial dan juga untuk mendapat dukungan dari stakeholder sehingga tujuan melakukan pengungkapan CSR murni sebagai bentuk tanggung jawab sosial kepada lingkungan dan masyarakat sekitar, bukan sebagai pengalihan isu kepada para stakeholder terkait praktik manajemen laba.

Hasil analisis $\mathrm{H}_{3}$, pengaruh kepemilikan instusional terhadap corporate social responsibility diperoleh nilai Sig. t sebesar 0,556 dengan nilai koefisien beta 0,106 
Nilai Sig. t 0,556 > 0,05 mengindikasikan bahwa $\mathrm{H}_{0}$ diterima dan $\mathrm{H}_{3}$ ditolak. Dari hasil ini dapat disimpulkan bahwa kepemilikan instusional tidak berpengaruh signifikan terhadap pengungkapan CSR. Hasil ini bertolak belakang dengan hasil penelitian oleh Setyarini and Paramitha (2011) yang menunjukkan bahwa kepemilikan institusional berpengaruh signifikan positif terhadap pengungkapan CSR dalam laporan tahunan perusahaan di Indonesia. Menurut Kamaliah (2010) dalam Fajrina (2014) yang memaparkan bahwa investor institusional memiliki kekuatan untuk bertanggung jawab dalam menerapkan corporate governance untuk melindungi hak dan kepentingan seluruh pemegang saham, sehingga mereka menuntut perusahaan untuk melakukan komunikasi secara transparan. Berdasarkan hasil diatas yang menunjukan bahwa hipotesis terkait kepemilikan institusional ditolak dapat terjadi disebabkan oleh para investor dari institusi yang menanamkan modal ke perusahaan tidak menjadikan masalah pengungkapan CSR sebagai tolak ukur sebelum menanamkan modalnya karena investasi tersebut hanya untuk jangka pendek. Hal ini sejalan dengan penelitian Djuitaningsih and Marsyah (2016) dan Fajrina (2014) yang juga menunjukan tidak adanya pengaruh dari kepemilikan instusional terhadap pengungkapan CSR. Jika hasil tersebut dikaitkan dengan teori sinyal tentu pengungkapan CSR dalam annual report dianggap tidak memberikan sinyal atau pengaruh terhadap calon atau para investor. Hal ini kemungkinan besar disebabkan adanya faktor lain seperti pengungkapan informasi terkait laporan keuangan yang berhubungan dengan laba atau rugi serta komponen keuangan lainnya yang dirasa cukup sebagai sinyal dalam menilai bagaimana kondisi perusahaan saat ini dan gambaran untuk masa 
mendatang sehingga mereka tidak menuntut perusahaan dalam mengungkapkan informasi terkait tanggung jawab sosialnya. Jadi besar atau kecilnya persentase kepemilikan saham institusional ke perusahaan tidak akan berpengaruh terhadap luasnya pengungkapan CSR.

Hasil analisis $\mathrm{H}_{4}$, pengaruh kepemilikan manajerial terhadap corporate social responsibility diperoleh nilai Sig. $\mathrm{t}$ sebesar 0,995 dengan nilai koefisien beta 0,001 Nilai Sig. t 0,995 > 0,05 mengindikasikan bahwa $\mathrm{H}_{0}$ diterima dan $\mathrm{H}_{1}$ ditolak. Hasil ini berarti bahwa Kepemilikan Manajerial berpengaruh negatif terhadap Corporate Social Responsibility. Hasil ini bertolak belakang dengan hasil penelitian Khan et al., (2013) menunjukkan adanya pengaruh yang positif dan signifikan antara kepemilikan manajemen terhadap corporate social responsibility namun mendukung hasil dari penelitian Djuitaningsih and Marsyah (2016) dan Fajrina (2014) yang menyatakan tidak adanya pengaruh antara kepemilikan manajerial dengan pengungkapan CSR, hal ini dapat disebabkan karena rata rata kepemilikan saham manajerial dalam suatu perusahaan masih relatif kecil, sehingga pihak manajemen tidak secara maksimal melaksanakan kegiatan CSR karena tidak adanya keuntungan secara signifikan bagi manajemen jika melakukan kegiatan CSR.

Hasil analisis $\mathrm{H}_{5}$ yaitu pengaruh Ukuran Dewan Komisaris terhadap Corporate Social Responsibility diperoleh nilai Sig. $\mathrm{t}$ sebesar 0,081 dengan nilai koefisien beta $-0,259$ Nilai Sig. t 0,081 > 0,05 mengindikasikan bahwa $\mathrm{H}_{0}$ diterima dan $\mathrm{H}_{1}$ ditolak. Hasil ini mempunyai arti bahwa Ukuran Dewan Komisaris berpengaruh negatif dan signifikan terhadap Corporate Social 
Responsibility. Hasil ini sejalan dengan penelitian yang dilakukan oleh Djuitaningsih and Marsyah (2016) dan Chakroun (2008) yang mengungkapkan tidak adanya pengaruh antara ukuran dewan komisaris dengan pengungkapan CSR. Dilihat dari hasil tersebut telah menunjukan bahwa ukuran dewan komisaris kurang memiliki pengaruh terhadap pengungkapan CSR. Hal ini bisa terjadi karena kemungkinan besar adanya karakteristik lain dari dewan direksi dari segi kompetensi atau indepedensi sehingga besar atau kecilnya ukuran dewan komisaris tidak dapat menjadi penentu adanya monitoring yang baik dalam pengungkapan CSR.

Hasil analisis $\mathrm{H}_{6}$ pengaruh Komite Audit terhadap Corporate Social Responsibility diperoleh nilai Sig. $\mathrm{t}$ sebesar 0,420 dengan nilai koefisien beta 0,127 Nilai Sig. t 0,420 >0,05 mengindikasikan bahwa $\mathrm{H}_{0}$ diterima dan $\mathrm{H}_{1}$ ditolak. Maka dapat disimpulkan bahwa komite audit tidak berpengaruh terhadap pengungkapan CSR. Hasil ini didukung dengan penelitian sebelumnya oleh Akhtaruddin et al., (2009) dan Waryanto (2010) yang mengungkapkan tidak adanya pengaruh antara komite audit dengan pengungkapan CSR. Dilihat dari hasil tersebut dapat disimpulkan bahwa peran komite audit dalam perusahaan sampel hanya sebatas memberikan pengawasan terkait masalah akuntansi, pelaporan keuangan,serta sistem audit internal, sehingga tidak melakukan pengawasan terkait pengungkapan CSR. Jika ditinjau dari sisi lain kemungkinan komite audit tidak berpengaruh terhadap pengungkapan CSR dikarenakan perusahaan membentuk komite audit hanya sebagai formalitas sehingga komposisi dan struktur komite audit kurang proporsional. 


\section{SIMPULAN}

Berdasarkan hasil penelitian yang telah dilakukan, dapat disimpulkan bahwa hanya kinerja lingkungan yang berpengaruh positif terhadap pengungkapan CSR, ini dapat diartikan bahwa kinerja lingkungan akan memperluas pengungkapan CSR karena pada periode bersangkutan perusahaan tambang telah melakukan pengelolaan lingkungan dengan baik sehingga perusahaan akan mengungkapkannya sebagai salah satu bentuk penerapan CSR di dalam laporan tahunan perusahaan yang akan menjadi informasi tambahan bagi para stakeholder maupun calon investor. Sedangkan hasil penelitian untuk variabel manajemen laba, kepemilikan institusional, kepemilikan manajerial, ukuran dewan komisaris dan komite audit telah menunjukan hasil bahwa tidak adanya pengaruh terhadap pengungkapan CSR.

Saran untuk penelitian selanjutnya dapat menggunakan sampel perusahaan lain agar dapat membandingkan hasil dari pengaruh kinerja lingkungan, manajemen laba, dan corporate governance pada perusahaan tambang dengan sampel perusahaan lain. Serta penelitian selanjutnya diharapkan dapat menambahkan variabel yang berkaitan dengan pengungkapan tanggung jawab sosial, misalnya : profitabilitas, ukuran perusahaan dan lainnya.

\section{REFRENSI}

Akhtaruddin, M. et al. (2009) 'Corporate Governance and Voluntary Disclosure in Corporate Annual Reports of Malaysian Listed Firms', JAMAR, 7(1).

Bahri, S. and Cahyani, F. A. (2016) 'Pengaruh Kinerja Lingkungan Terhadap Corporate Financial dengan Corporate Social Responsibility sebagai Variabel Intervening', Jurnal Ekonomi Universitas Kadiri, 1, pp. 117-142. 
Chakroun, H. M. dan R. (2008) Board Composition, ownership Structure and Voluntary Disclosure in Annual Reports: Evidence from Tunisia'. Laboratoire Interdisciplinaire de Gestion Universite- Enterprise (LIGUE)', (May 2014).

Dechow, P. M., Sloan, R. G. and Sweeney, A. P. (1995) 'The Accounting Review, pp. 195-225.

Djuitaningsih, T. and Marsyah, W. A. (2016) 'Pengaruh Manajemen Laba Dan Mekanisme Corporate Governance Terhadap', Media Riset Akuntansi, 2, pp. 187-211.

Fajrina, R. (2014) 'Pengaruh Lingkungan, Kepemilikan Manajerial, Kepemilikan Institusional, Manajemen Laba dan Solvabilitas Terhadap Pengungkapan Tanggung Jawab Sosial Perusahaan (Studi Empiris Pada Perusahaan yang Terdaftar di Bursa Efek Indonesia tahun 2009-2011)', Jurnal Akuntansi, pp. $1-26$.

Jayanti, K. R. (2018) 'Pengaruh Good Corporate Governance Dan Profitabilitas Terhadap Pengungkapan Corporate Social Responsibility (Studi pada Perusahaan Sektor Pertambangan yang Terdaftar di Bursa Efek Indonesia Periode 2015-2016 )', Jurnal Administrasi Bisnis (JAB), 59(1), pp. 16-22.

Khan, A., Muttakin, M. B. and Siddiqui, J. (2013) 'Corporate Governance and Corporate Social Responsibility Disclosures: Evidence from an Emerging Economy', Journal of Business Ethics, 114(2), pp. 207-223.

Machmuddah, Z. et al. (2017) 'Manajemen Laba, Pengungkapan Lingkungan Perusahaan dan Mekanisme Tata Kelola Perusahaan', Jurnal Dinamika Akuntansi dan Bisnis, 4(1), pp. 57-72.

Muhammad Titan Terzaghi (2016) 'Pengaruh Earning Management Dan Mekanisme Corporate Governance Terhadap Pengungkapan Tanggung Jawab Sosial', Jurnal Ekonomi dan Informasi Akuntansi (JENIUS), 7(1), pp. $31-47$.

Ningsaptiti, R. (2010) 'Analisis Pengaruh Ukuran Perusahaan dan Mekanisme Corporate Governance Terhadap Manajemen Laba (Studi Empiris Pada Perusahaan Manufaktur yang Terdaftar di Bursa Efek Indonesia 2006 2008)', Skripsi.

Pasaribu, R., Kowanda, D. and Kurniawan, D. (2015) 'Pengaruh Earning Management Dan Mekanisme Good Corporate Governance Terhasap Pengungkapan Corporate Social Responsibility Pada Emitmen Manufaktur Di Bursa Efek Indonesia', Riset Manajemen Dan Bisnis, 10(2), pp. 97-121. 
Purwanto, A. (2011) 'Pengaruh Tipe Industri, Ukuran Perusahaan, Profitabilitas Terhadap Corporate Social Responsibility', Akuntansi \& Auditing, 8(November), pp. 13-29.

Sembiring, E. R. (2005) 'Karakteristik Perusahaan dan Pengungkapan Tanggung Jawab Sosial: Studi Empiris pada Perusahaan yang Tercata di Bursa Efek Indonesia', Simposium Nasional Akuntansi XVI, (September), pp. 379-395.

Setyarini, Y. and Paramitha, M. (2011) 'Pengaruh Mekanisme Good Corporate Governance Terhadap Corporate Social Responsibility', Spectrochimica Acta - Part A: Molecular and Biomolecular Spectroscopy, 149, p. 1021.

Sudaryanto (2011) 'Pengaruh Kinerja Lingkungan terhadap Kinerja Finansial Perusahaan dengan Corporate Social Responsibility (CSR) Disclousure sebagai Variabel Intervening'.

Tito Anindito, M. D. A. 1 J. (2015) 'Pengaruh Kinerja Lingkungan Terhadap Corporate Social Responsibility (CSR) Disclosure dan Kinerja Finansial Perusahaan Kimia dan Pertambangan Yang Terdaftar Di Bursa Efek Indonesia (Studi Empiris Pada Perusahaan Pertambangan Yang Terdaftar dalam BEI tahun', Diponegoro Journal of Accounting, 2, pp. 1-12.

Waryanto (2010) 'Pengaruh Karakteristik Good Corporate Governance (GCG) Terhadap Luas Pengungkapan Corporate Social Responsibility (CSR) di Indonesia'.

www.menlh.co 